\title{
Komparasi Penerapan Kinerja Inverter pada Sistem Refrigerasi dengan Alat Ekspansi Jenis TXV dan Pipa Kapiler
}

\author{
Rizki Muliawan ${ }^{1}$, Muhammad Ghanim ${ }^{1}$,Tandi Sutandi ${ }^{1}$ \\ ${ }^{1}$ Jurusan Teknik Refrigerasi dan Tata Udara, Politeknik Negeri Bandung \\ email : rizki.muliawan@polban.ac.id,
}

\begin{abstract}
Abstrak
Konsumsi daya listrik untuk sistem tata udara memiliki angka sekitar $\pm 60 \%$ dari total konsumsi energi listrik suatu bangunan, sama halnya dengan aplikasi pada sistem refrigerasi skala kecil domestik seperti lemari es (refrigerator) yang membutuhkan konsumsi yang tidak sedikit. Terdapat beberapa alat kontrol kendali maupun equipment device yang dapat dipergunakan sebagai teknologi penghematan diantaranya Inverter. Teknologi inverter akan coba diaplikasikan pada sistem refrigerasi kompresi uap dengan dua variasi metering device yang berbeda yaitu Thermostatic Expansion Valve (TXV) dan pipa kapiler (capillary tube). Metode penelitian yang akan dilaksanakan diawali dengan kajian teknologi refrigerasi kemudian dilanjutkan secara lebih mendalam pada teknologi inverter, dan metering device yang saat ini berkembang. Alat kemudian dirancang bangun lalu di uji coba hasilnya. Dari hasil penelitian didapatkan COP TXV lebih besar dari pipa kapiler sebesar 3,97 berbanding 2,77 dan efisiensi yang dihasilkan menggunakan TXV lebih tinggi yaitu sebesar 78,95\% sedangkan dengan pipa kapiler 75,42\%. Daya listrik dengan memakai TXV dan kapiler berturut-turut 352 Watt dan 242 Watt. Temperatur kabin dan produk dapat dicapai dalam waktu 35 menit untuk TXV dan 105 menit untuk kapiler. Hasil penelitian dapat disimpulkan kinerja sistem lebih baik menggunakan inverter dengan katup ekspansi jenis TXV.
\end{abstract}

Kata Kunci : refrigerasi; cop; inverter; txv; pipa kapiler;

\section{PENDAHULUAN}

\section{I.1 Latar Belakang}

Saat ini isu dan dampak bagi lingkungan sangat diperhatikan (concern) terkait dengan Pemanasan Global (Global Warming Potential) dan efek penipisan lapisan ozon (Ozone Depletion Potential) [1]. Mengacu pada permasalahan tadi maka, diperlukan teknologi penghematan sebagai bagian dari konservasi energi. Konsumsi daya listrik untuk pengondisian udara lazim disebut HVAC memiliki angka sekitar 50-60\% dari total konsumsi energi listrik suatu bangunan sama halnya dengan aplikasi pada sistem refrigerasi skala kecil (domestik) seperti lemari es (refrigerator) yang membutuhkan konsumsi yang tidak sedikit $[2,3,13]$. Teknologi untuk penghematan energi listrik semakin berkembang dari waktu ke waktu. Terdapat beberapa alat kontrol kendali maupun equipment device yang dapat dipergunakan sebagai teknologi penghematan diantaranya inverter, Variabel Speed Drive (VSD) dan lain sebagainya.
Inverter adalah suatu perangkat elektronik daya yang dapat dipergunakan untuk mengubah (konversi) tegangan searah (DC) ke suatu tegangan bolak-balik (AC) dengan cara mengatur frekuensinya $[2,14]$. Sehingga putaran motor kompresor dapat diatur, supaya temperatur Lemari pendingin dapat terjaga sesuai dengan kebutuhan selain itu kompresor tidak terjadi $O n$ Off secara terus menerus yang dapat berakibat terhadap konsumsi daya menjadi tinggi.

Hasil kajian penelitian dari Marwan dan Nasution melaporkan bahwa dengan memvariasikan putaran kompresor torak dengan cara merubah frekuensi dari 20 hingga $50 \mathrm{~Hz}$ telah dihasilkan penghematan konsumsi energi listrik sebesar 8,5\% hingga 24,9\% [3,4]. Hasil kajian dari Sumeru, juga melaporkan peningkatan kinerja (COP) cold storage dengan memvariasikan putaran kompresor dengan merubah frekuensi listrik dari $25 \mathrm{~Hz}$ hingga $45 \mathrm{~Hz}$. Penurunan putaran kompresor 
sekaligus akan menurunkan pula daya input ke dalam sistem. Hasil penelitiannya juga melaporkan bahwa semakin rendah putaran kompresor, semakin meningkat COP sistem. Peningkatan COP maksimal pada pengujian adalah sebesar $17,5 \%$ pada frekuensi listrik $25 \mathrm{~Hz}$ [5].

\section{I.2 Tujuan Penelitian}

Tujuan penelitian ini adalah untuk menganalisis dan membandingkan dari performa kerja (kinerja) dari inverter dengan menggunakan katup ekspansi jenis TXV dan pipa kapiler serta daya dari energi listrik.

\section{I.3 Rumusan Masalah}

Diperlukan suatu kajian untuk mengetahui performa kerja (kinerja) sistem kompresi uap dengan teknologi inverter pada katup ekspansi jenis TXV dan pipa kapiler serta daya energi listrik dari sistem kompresi uap yang dipergunakan.

\section{KAJIAN PUSTAKA (DASAR TEORI)}

\section{II.1 Refrigerasi}

Refrigerasi adalah proses penyerapan panas dari suatu ruangan atau kabin sehingga temperaturnya berada di bawah temperatur lingkungan. Pada umumnya komponen utama mesin pendingin adalah kompresor, kondensor, evaporator dan alat ekspansi $[6,7,8]$.

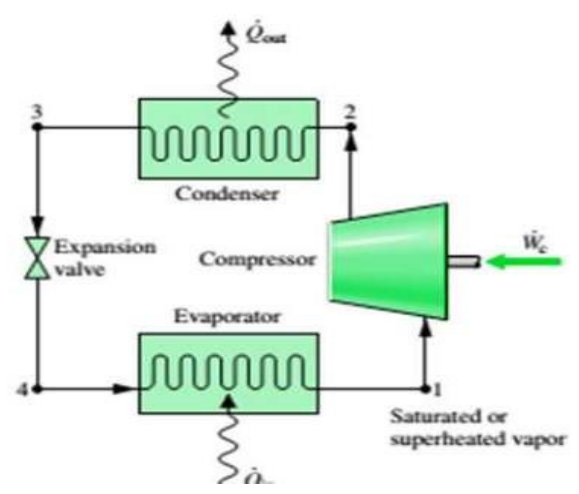

Gambar 1. Sistem refrigerasi $[9,10]$

\section{II.2 Lemari Pendingin (refrigerator)}

Lemari pendingin merupakan salah satu alat elektronik yang melibatkan sistem refrigerasi atau sebagai tempat penyimpanan makanan atau minuman agar terhindar dari serangga-serangga yang berada di rumah dan juga agar rasa makanan atau minuman tidak berubah dan terhindar dari timbulnya jamur pada setiap makanan atau minuman. Sehingga lemari pendingin dibutuhkan pada setiap rumah tangga [11].

\section{II.3 Siklus Kompresi Uap}

P-h Diagram

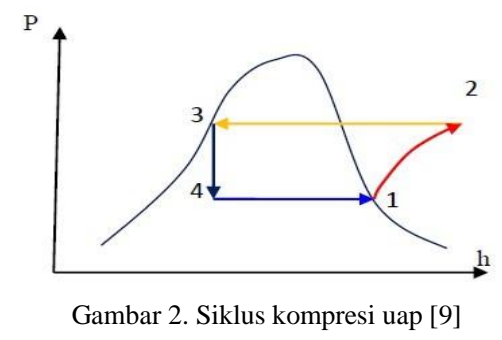

Keterangan:

1 - 2: Proses Kompresi

$2-3$ : Proses Kondensasi

3 - 4: Proses Ekspansi

4 - 1: Proses Evaporasi

a. Proses Kompresi (proses 1-2)

Refrigeran dari evaporator kemudian dihisap oleh kompresor dan selanjutnya mengalami proses kompresi. Saat proses kompresi refrigeran akan mengalami kenaikan tekanan dan temperatur sehingga refrigeran keluar kompresor berfasa uap dan panas. Menurut Dossat [12] besarnya kerja kompresi dapat dihitung menggunakan Persamaan 1.

$$
\mathbf{w}=\mathbf{h}_{2}-\mathbf{h}_{1}
$$

\section{Keterangan:}

$\mathrm{w}=$ kerja kompresi, $[\mathrm{kJ} / \mathrm{kg}]$.

$\mathrm{h}_{2}=$ entalpi refrigeran keluar kompresor, $[\mathrm{kJ} / \mathrm{kg}]$.

$\mathrm{h}_{1}=$ entalpi refrigeran masuk kompresor, $[\mathrm{kJ} / \mathrm{kg}]$.

\section{b. Proses Kondensasi (proses 2-3)}

Refrigeran yang keluar dari kompresor akan dialirkan ke kondensor dan mengalami proses kondensasi. Selanjutnya saat berada di kondensor refrigeran tersebut mengalami penurunan temperatur dikarenakan uap refrigeran melepaskan panas ke lingkungan, sehingga fasa refrigeran akan berubah fasa dari gas menjadi cair. Besarnya panas yang dilepaskan di kondenser dapat dihitung menggunakan persamaan 2 .

$$
q_{c}=h_{2}-h_{3} \ldots \text { (2) }
$$

\section{Keterangan:}

$\mathrm{qc}=$ panas yang dilepas oleh kondenser, $[\mathrm{kJ} / \mathrm{kg}]$.

$\mathrm{h}_{2}=$ entalpi refrigeran yang keluar dari kompresor, $[\mathrm{kJ} / \mathrm{kg}]$. $\mathrm{h}_{1}=$ entalpi refrigeran yang keluar dari kondenser, $[\mathrm{kJ} / \mathrm{kg}]$. 
c. Proses Ekspansi (proses 3-4)

Refrigeran dengan fasa cair dan bertekanan tinggi dari kondensor akan disalurkan ke alat ekspansi kemudian mengalami proses penurunan temperatur dan tekanan. Refrigeran berubah fasa menjadi campuran uap dan cairan dengan fasa dominan cair. Secara umum, dalam proses ekspansi ini maka berlaku persamaan 3 .

$$
\mathbf{h}_{3}=\mathbf{h}_{4}
$$

Keterangan:

$\mathrm{h}_{3}=$ entalpi refrigeran masuk alat ekspansi, [kJ/kg].

$\mathrm{h}_{4}=$ entalpi refrigeran keluar alat ekspansi, $[\mathrm{kJ} / \mathrm{kg}]$

\section{d. Proses Evaporasi (proses 4-1)}

Refrigeran selanjutnya dialirkan ke evaporator untuk menyerap panas dari benda yang akan didinginkan, sehingga refrigeran berubah fasa menjadi uap bertekanan rendah. Besarnya panas yang diserap oleh evaporator dihitung menggunakan persamaan 4 di bawah ini.

$$
\mathbf{q}_{\mathrm{e}}=\mathbf{h}_{1}-\mathbf{h}_{4} \text {. }
$$

Keterangan:

$\mathrm{qe}=$ panas yang diserap oleh evaporator, $[\mathrm{kJ} / \mathrm{kg}]$.

$\mathrm{h}_{1}=$ entalpi refrigeran masuk kompresor, $[\mathrm{kJ} / \mathrm{kg}]$.

$\mathrm{h}_{4}=$ entalpi refrigeran masuk evaporator, $[\mathrm{kJ} / \mathrm{kg}]$

\section{II.4 Inverter}

Inverter berfungsi untuk mengkonversikan dari DC (tegangan searah) ke AC (tegangan bolak-balik) dengan frekuensi yang dapat di ubah sesuai kapasitas kompresor.

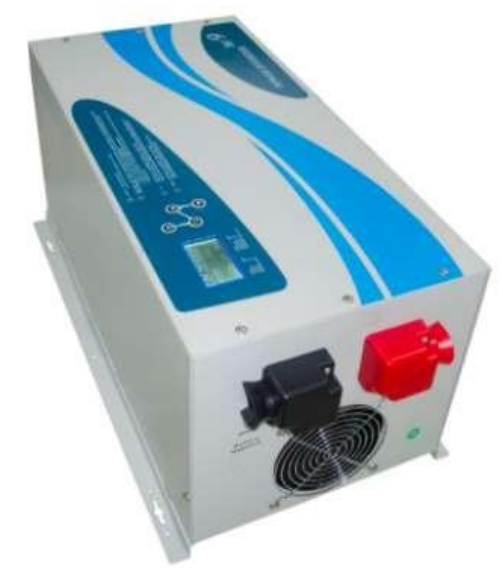

Gambar 3. Inverter [14]

\section{METODOLOGI}

\section{III.1 Waktu dan Tempat Penelitian}

Penelitian dilakukan di laboratorium Teknik Refrigerasi dan Tata Udara (POLBAN). Waktu penelitian sekitar 4 bulan dari Juli sampai dengan Oktober 2020.

\section{III.2 Bahan dan Alat}

Berupa alat uji trainer sistem refrigerasi lemari pendingin yang telah dirakit menggunakan inverter dan dengan dua alat ekspansi yaitu TXV serta pipa kapiler.

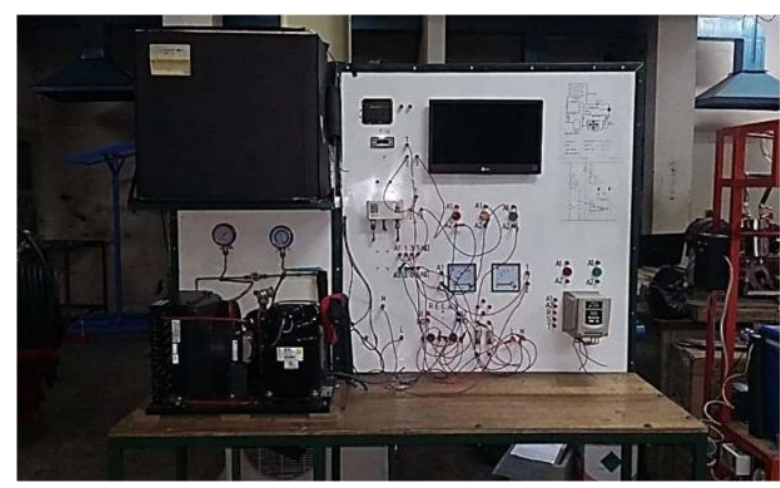

Gambar 4. Alat uji trainer refrigerasi

Kelengkapan Condensing unit :

- Kompresor Tecumseh

- Jenis kompresor Hermetic dan daya $=1 / 2$ pk, condenser

- Merk Kompresor Tecumseh

- Jenis Refrigeran R134a

- Alat ekspansi menggunakan TXV Danfoss dan pipa kapiler. 


\section{III.3 Langkah-langkah Penelitian}

Langkah-langkah penelitian dari Gambar 5 di bawah ini, dengan menentukan beberapa hal berikut ini :
a) Menyiapkan alat uji dalam penelitian ini
b) Sistem di cek kebocoran lalu di vacuum
c) Sistem kemudian diisi dengan refrigeran (R134a)
d) Pilih jenis katup ekspansi : TXV dan pipa kapiler
e) Menyalakan sistem sampai dengan kondisi stedi (tetap)
f) Mengambil data dan mencatatnya.
g) Menganalisis dan olah data

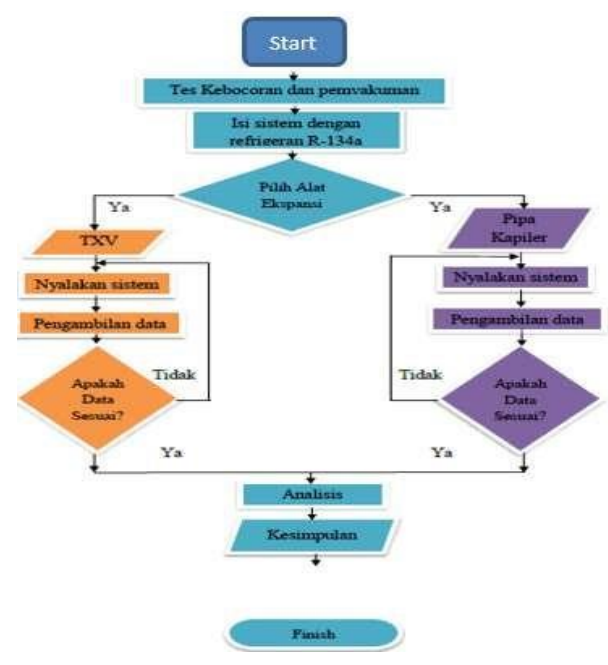

Gambar 5. Alur langkah pengerjaan penelitian

\section{III.4 Variabel Penelitian}

Variabel-variabel dalam penelitian ini, diantaranya:

- Variabel bebas : interval waktu tertentu $(0,5,10,15,120$ dan steady state $)$ dan jenis alat ekspansi (Kapiler dan TXV)

- Variabel terikat : efek refrigerasi, kerja kompresi, COP dain lainnya

- Variabel kontrol : temperatur produk, temperatur dalam kabin

Diagram alir penelitian ditunjukan pada gambar 6 ini

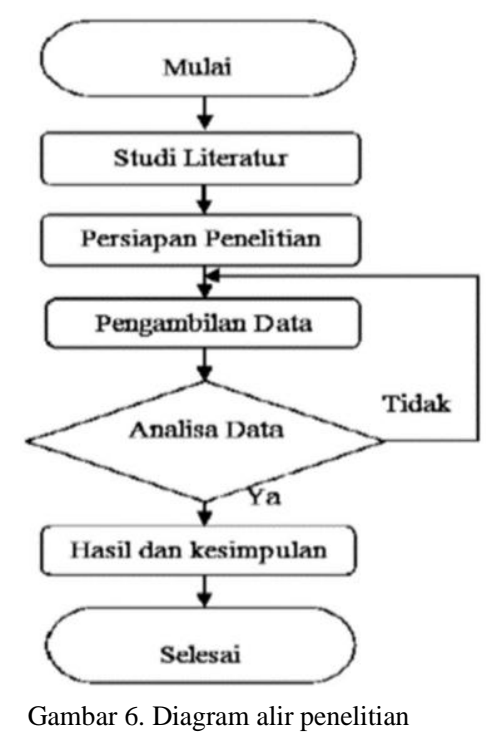

Diagram pemipaan trainer sistem refrigerasi lemari pendingin diperlihatkan seperti Gambar 7 berikut di bawah ini.

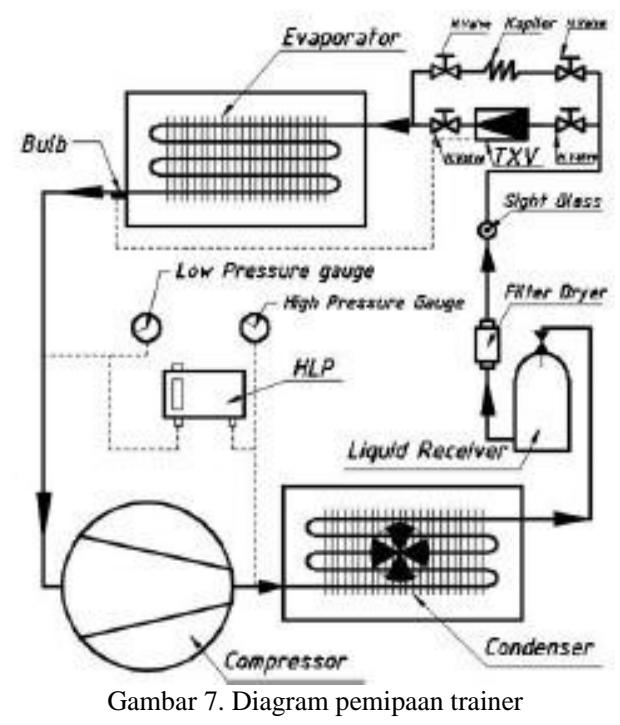

Titik-titik pengukuran yang dilakukan dalam penelitian ini adalah sebagai berikut ini :

- Temperatur discharge

- Temperatur out condenser

- Temperatur suction

- Temperatur kabin

- Temperatur produk

- Tekanan discharge

- Tekanan suction

- Temperatur lingkungan

- Tegangan listrik

- Arus listrik

- Daya 
Titik pengukuran di atas tadi dapat dilihat pada Gambar 8 di bawah ini :

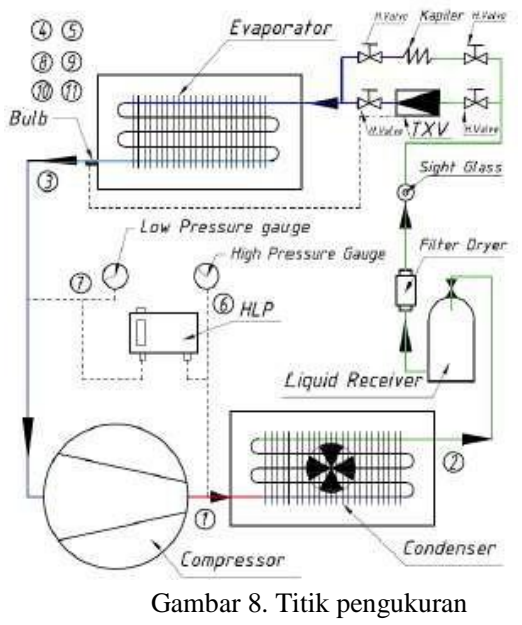

Wiring kelistrikan dideskripsikan pada Gambar 9 di bawah ini.

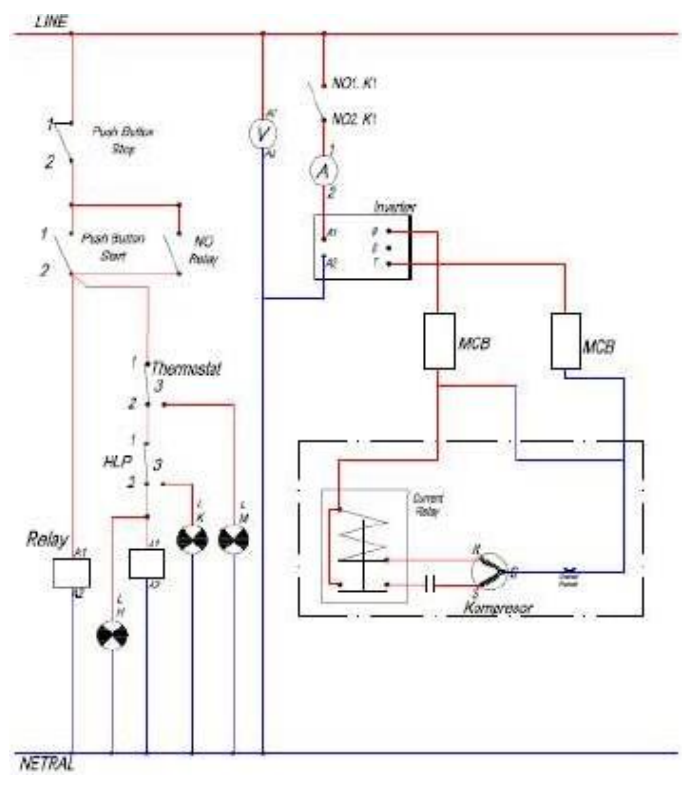

Gambar 9. Diagram kelistrikan

\section{HASIL DAN PEMBAHASAN}

\section{Setelah alat dirakit dan di uji kemudian diambil data kinerjanya.}

\section{IV.1 Hasil Data Penelitian}

Data hasil pengamatan penelitian untuk TXV dan Pipa kapiler :

\section{IV.1.1 Data TXV}

Data TXV yang diamati adalah pada saat keadaan stedi yaitu pada menit ke-30.

Tekanan Suction $(P s)=0,4$ bar

Tekanan discharge $(P d)=7,1$ bar

Temperatur suction $(T s)=-11,97^{\circ} \mathrm{C}$

$T_{\text {out kondensor }}=27,63{ }^{\circ} \mathrm{C}$
Data-data tersebut di atas kemudian di plot ke diagram P-h dengan menggunakan software coolpack.

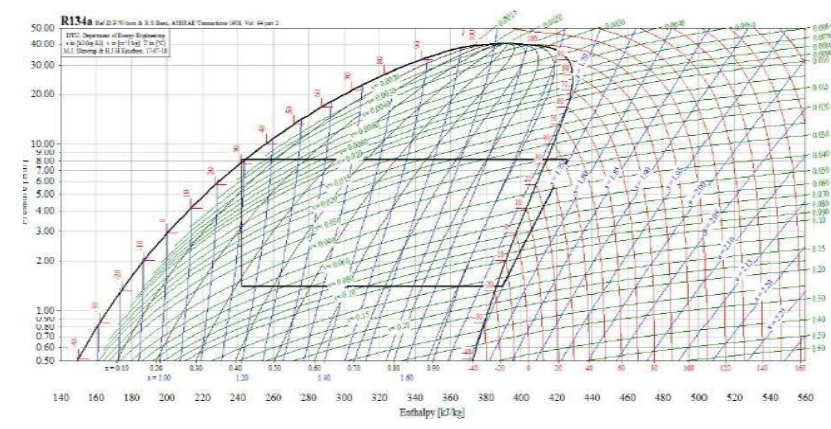

Gambar 10. Hasil Plot R-134a pada P-h diagram pada keadaan stedi (tetap) yaitu pada menit ke- 30

Plot selesai kemudian didapat data-data sbb:

$h_{1}=389,256 \mathrm{~kJ} / \mathrm{kg}$

$h_{2}=426,241 \mathrm{~kJ} / \mathrm{kg}$

$h 3=h 4=242,374 \mathrm{~kJ} / \mathrm{kg}$

Te $($ Evaporator $)=-18,80+273,15=254,35 \mathrm{~K}$

$T c($ Condenser $)=31,77+273,15=304,92 \mathrm{~K}$

Didapatkan hasil sebagai berikut :

- Kerja kompresi $(q w)=36,985 \mathrm{~kJ} / \mathrm{kg}$

- Kalor yang dilepas kondensor $(q c)=183,867 \mathrm{~kJ} / \mathrm{kg}$

- Efek refrigerasi $(q e)=146,882 \mathrm{~kJ} / \mathrm{kg}$

- $C O P_{\text {aktual }}=3,971$

- $C O P_{\text {carnot }}=5,029$

- Efisiensi $=78,959 \%$

- Rasio kompresi = 5,785

\section{IV.1.2 Pipa Kapiler}

Data pipa kapiler yang diamati adalah pada saat keadaan stedi yaitu pada menit ke-100.

Tekanan Suction $(P s)=-0,33$ bar

Tekanan discharge $(P d)=6,7$ bar

Temperatur suction $(T s)=-0,25^{\circ} \mathrm{C}$

$T_{\text {out kondensor }}=26,37^{\circ} \mathrm{C}$

Data-data tersebut di atas kemudian diplot ke diagram P-h dengan menggunakan software coolpack.

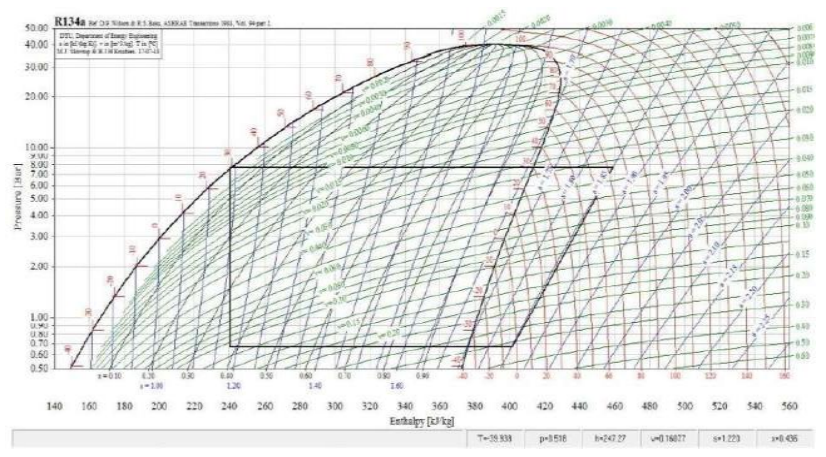

Gambar 11. Hasil Plot R-134a pada P-h diagram pada keadaan stedi (tetap) yaitu pada menit ke- 100 . 
Plot selesai kemudian didapat data-data sbb:

$$
\begin{aligned}
& h_{1}=401,208 \mathrm{~kJ} / \mathrm{kg} \\
& h_{2}=459,186 \mathrm{~kJ} / \mathrm{kg} \\
& h 3=h 4=240,553 \mathrm{~kJ} / \mathrm{kg} \\
& T e(\text { Evaporator })=-34,86+273,15=238,29 \mathrm{~K} \\
& T c(\text { Condenser })=30+273,15=303,15 \mathrm{~K}
\end{aligned}
$$

Perhitungan dari formula didapatkan hasil sebagai berikut :

- Kerja kompresi $(q w)=57,978 \mathrm{~kJ} / \mathrm{kg}$

- Kalor yang dilepas kondensor $(q c)=218,633 \mathrm{~kJ} / \mathrm{kg}$

- Efek refrigerasi (qe) $=160,655 \mathrm{~kJ} / \mathrm{kg}$

- $C O P_{\text {aktual }}=2,77$

- $C O P_{\text {carnot }}=3,67$

- Efisiensi $=75,476 \%$

- Rasio kompresi $=11,492$

\section{IV.1.3 Daya Listrik}

Data yang digunakan untuk menghitung besarnya konsumsi energi listrik pada TXV pada menit ke-30, sedangkan sistem pada pipa kapiler yaitu data pada menit ke-100.

Perhitungan untuk mendapatkan besaran energi listrik kedua jenis alat ekspansi tadi adalah seperti berikut;

a. Daya listrik menggunakan TXV =

$$
\begin{aligned}
\mathrm{P} & =\mathrm{V} \times \mathrm{I} \times \text { Cosphi } \\
& =220 \text { Volt } \times 3,2 \mathrm{~A} \times 0,5 \\
& =352 \text { Watt }
\end{aligned}
$$

b. Daya listrik menggunakan kapiler =

$$
\begin{aligned}
\mathrm{P} & =\mathrm{V} \times \mathrm{I} \times \text { Cosphi } \\
& =220 \text { Volt } \times 2,2 \mathrm{~A} \times 0,5 \\
& =242 \text { Watt }
\end{aligned}
$$

\section{IV.2 Analisa Pembahasan}

Data-data yang telah didapat, kemudian dianalisis dan dideskripsikan dalam bentuk grafik data sebagai fungsi dari waktu, sbb :

- $\quad$ Analisis Arus Listrik Terhadap Waktu

- Analisis $\mathrm{COP}_{\text {aktual }}$

- Analisis $\mathrm{COP}_{\text {carnot }}$

\section{- Analisis Efisiensi}

\section{IV.2.1 Analisis Arus Listrik Terhadap Waktu}

Grafik Arus listrik sebagai fungsi waktu ditunjukan dari Gambar 12. di bawah ini menunjukan bahwa perbedaan arus yang diperlukan untuk masing-masing katup ekspansi antara TXV dan pipa kapiler berbeda.

Arus listrik pada saat kompresor mati (cut out) adalah nol Ampere (A), untuk katup ekspansi TXV besaran arus listrik adalah di range 3,2 A sampai dengan 3,8 A. Pipa kapiler arus listrik berkisar antara 2,1 A sampai 2,8 A hal ini disebabkan karena pada sistem dengan menggunakan pipa kapiler tidak sering terjadi hidup mati kompresor (cut in dan cut out).

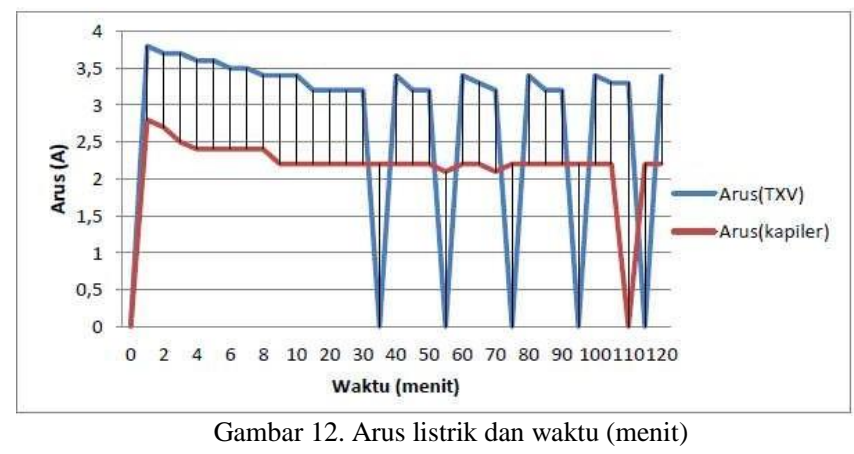

\section{IV.2.2 Analisis COP aktual Terhadap Waktu}

Gambar 13 di bawah ini menunjukan bahwa $\mathrm{COP}_{\text {aktual }}$ dengan sistem menggunakan alat ekspansi TXV dan pipa kapiler.

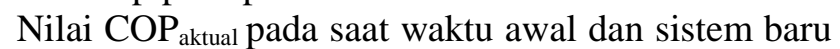
menyala memiliki nilai yang relative besar hal ini disebabkan oleh belum stabilnya sistem. Tekanan (suction, discharge) dan temperaturnya masih tinggi. Penuruan COPaktual akan kembali terjadi ketika kondisi steady state tercapai.

Sistem menggunakan alat ekspansi TXV kondisi konstan pada menit ke-25 menit dan memiliki nilai COPaktual berkisar antara 3,971 sampai 4,596. Pipa kapiler memiliki $\mathrm{COP}_{\text {aktual }}$ berkisar antara 2,752 sampai 2,865 untuk nilainya hampir konstan dari menit awal.

Hasil dari perbandingan COP kedua jenis katup ekspansi menunjukan sistem menggunakan katup ekspansi TXV memiliki nilai COP $_{\text {aktual yang lebih besar }}$ dibandingkan dengan pipa kapiler.

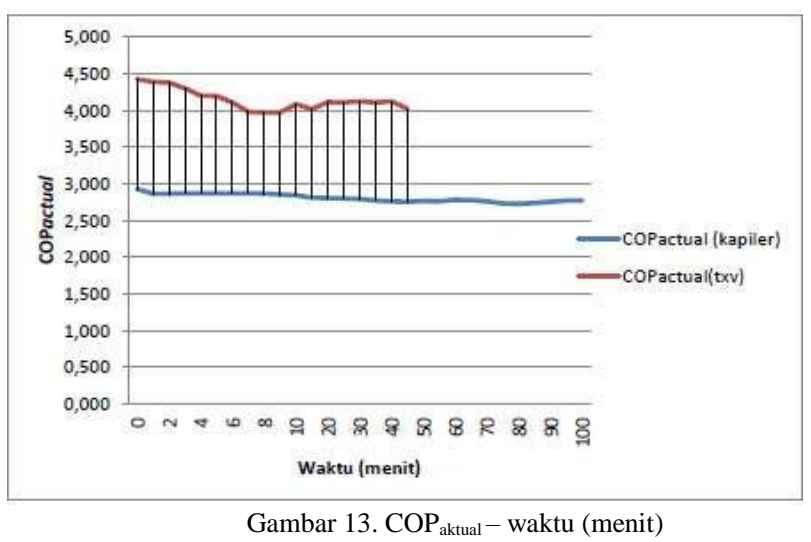




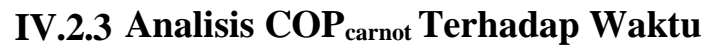

Grafik pada gambar 14 ini ditunjukan sistem menggunakan alat ekspansi pipa kapiler dan TXV. Terlihat dari grafik pada menit awal $\mathrm{COP}_{\text {carnot }}$ memiliki nilai yang besar dikarenakan beban masih tinggi yang disebabkan temperatur kondensasi (Tk) dan (Te) evaporasi mengalami kenaikan. Sistem saat menggunakan alat ekspansi pipa kapiler memiliki nilai $\mathrm{COP}_{\text {carnot }}$ dari menit awal hingga akhir sekitar antara 3,725 sampai dengan 3,634. Sistem memakai alat ekspansi TXV memilik COP $_{\text {carnot }}$ turun naik hal ini disebabkan pada sistem terjadi cut in dan cut out sampai menit akhir, adapun nilainya antara 5,029 sampai 5,537. Hasil tersebut menunjukan bahwa sistem dengan menggunakan alat ekspansi TXV memiliki nilai $\mathrm{COP}_{\text {carnot }}$ yang lebih besar daripada sistem memakai pipa kapiler.

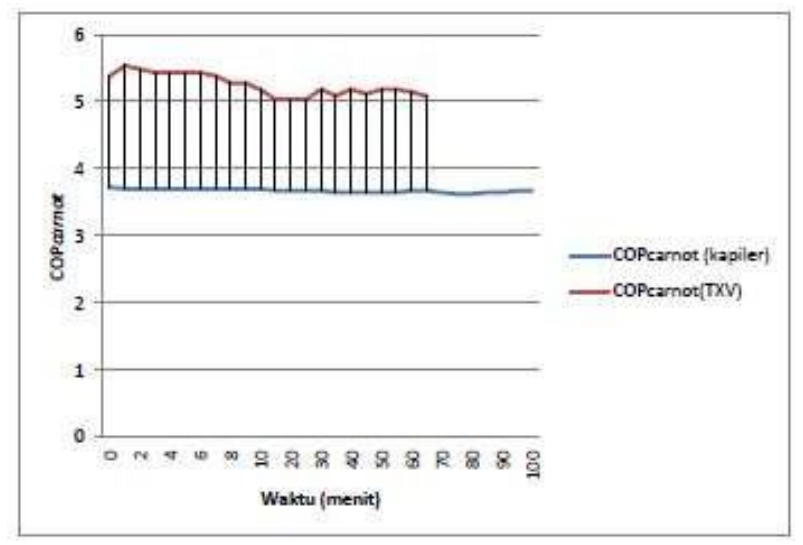

Gambar 14. $\mathrm{COP}_{\text {carnot }}-$ waktu (menit)

\section{IV.2.4 Analisis Efisiensi Terhadap Waktu}

Grafik Gambar 15. Efisiensi masing-masing katup ekspansi, nilai besaran ini sangat dipengaruhi oleh nilai $\mathrm{COP}_{\text {carnot }}$ dengan $\mathrm{COP}_{\text {aktual. Semakin tinggi nilai }}$ $\mathrm{COP}_{\text {aktual }}$ dan berbanding terbalik dengan $\mathrm{COP}_{\text {carnot, }}$ maka efisiensi akan bernilai tinggi. Persamaannya pada awal mula efisiensi bernilai tinggi, kemudian seiring waktu turun. Dilihat dari gambar efisiensi untuk TXV lebih tinggi dari pipa kapiler. Efisiensi untuk TXV berkisar antara $78 \%$ sampai dengan $83 \%$. Pipa kapiler memiliki efisiensi yang cenderung stabil penurunannya kalau dilihat dari gambar yaitu sekitar 75,09 \% sampai dengan $75,88 \%$ walaupun pada awal mula besar sekitar $78,61 \%$ karena sistem belum stedi.

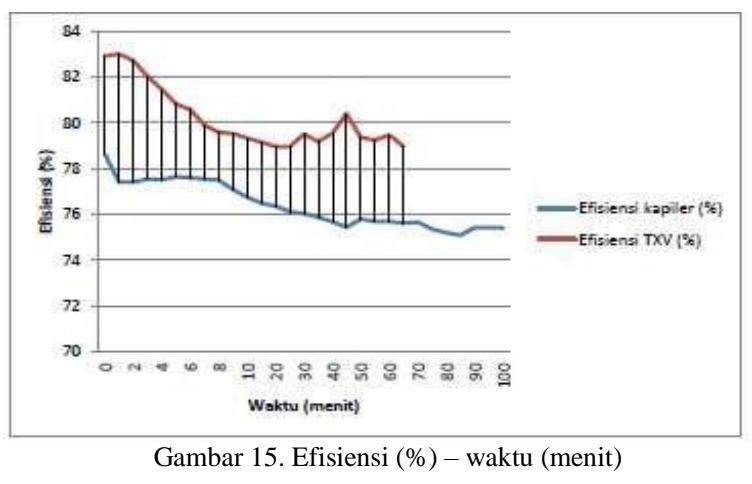

\section{KESIMPULAN}

Dari hasil penelitian ini didapatkan nilai COP TXV sebesar 3,97 dan menggunakan pipa kapiler sebesar 2,77 dan efisiensi yang dihasilkan menggunakan TXV lebih tinggi yaitu sebesar 78,95\% sedangkan dengan pipa kapiler $75,42 \%$. Daya listrik dengan memakai TXV dan kapiler berturut-turut 352 Watt dan 242 Watt. Temperatur Kabin dan produk dapat dicapai dalam waktu 35 menit untuk TXV dan 105 menit untuk kapiler. Hasil dari analisis perhitungan dapat disimpulkan bahwa kinerja yang paling baik adalah inverter dengan menggunakan TXV dibandingkan dengan pipa kapiler.

\section{DAFTAR PUSTAKA}

[1] R Muliawan, Effect of Leakage on Refrigerant Distribution in Air Conditioned Room Using Propane as Working Fluid," in Proceding ICIEVE UPI, 2020.

[2] I Welid, "Kaji experimental perbandingan kinerja pengkondisi udara antara menggunakan inverter dan non-inverter," in Seminar Prosiding Nasional Edusaintek Unimus, 2019.

[3] Marwan,"Energy Saving in an Air-Conditioning System Using an Inverter and a Temperature-Speed Controller," Universiti Teknologi Malaysia, $\mathrm{PhD}$ Thesis, 2004.

[4] Nasution, H., Sumeru, K., Azhar, A.A., Senawi, M.Y., Experimental study of air conditioning control system for building energy saving, Energy Procedia Vol. 61,pp.63-66, 2014.

[5] Sumeru, K. dan Sutandi T., "Penghematan energi pada mesin pendingin dengan variasi putaran kompresor," Jurnal Teknik Mesin Institut Teknologi Sepuluh November Vol.7 no.2, pp. 80-85, 2007.

[6] Stoecker Refrigerasi dan Pengkondisian Udara, Erlangga,Jakarta. 1996

[7] AD Pasek. Retrofit Sistim Refrigerasi dan Pengkondisian Udara Ramah Lingkungan, Pusat Pendidikan dan Pelatihan Kementerian Lingkungan Hidup, Jakarta.

[8] "Pengertian Refrigerasi".[online]. Tersedia http://id.wikipedia.org/wiki/Refrigerasi [diakses tanggal 5 April 2020].

[9] Moran, M., J, Saphiro,"Fundamentals of Engineering Thermodynamics," Jhon Wiley \& Sons, Inc. : London, 2011.

[10]Cengel. Yunus A and Michael A Boles, "Thermodynamics : An Engineering Approach 5th edition : McGraw-Hill, 2014.

[11] Arora C. P, " Refrigeration and Air Conditioning ," 2010.

[12] Roy J dosat. Refrigeration. 1961

[13] Ortiz, J., Pout, C., "A review on buildings energy consumption information. Energy and Buildings," Vol. 40 no. 3, pp. 394-398, 2008.

[14] https://indonesian.alibaba.com/product-detail/solar-panel-systempower-inverter-dc-to-ac-converter-use-in-household60543516157.html [diakses tanggal 13 september 2020] 